\title{
A CLINICAL STUDY OF N-TERMINAL PRO-BNP LEVELS IN CONGESTIVE HEART FAILURE
}

\author{
Laxme Gowda1, Basava Raju M. M²
}

${ }^{1}$ Associate Professor, Department of Medicine, Mysore Medical College and Research Institute, Mysore. ${ }^{2}$ Associate Professor, Department of Medicine, Mysore Medical College and Research Institute, Mysore.

\begin{abstract}
BACKGROUND

Heart failure is one of the leading causes of morbidity and mortality in the Populations across the globe, as it is a common end point of many diseases viz. coronary artery diseases, cardiomyopathies, hypertension and many others enumerated in the forthcoming sections. So methodical management of this ailment will play a vital role in preventing unnecessary mortality and morbidity. Lot of research has been done in relation to better understanding of the pathophysiology of this disease as well as in the diagnostic and therapeutic techniques related to heart failure till date. Echocardiography in particular, has revolutionised the diagnosis of heart failure. In the forthcoming sections is on a very simple and quick method of diagnosis of heart failure viz. NT-pro BNP level estimation, which neither needs the echocardiography gadgets nor a skilled echotechnician/cardiologist to interpret the echocardiographic images. This might prove very handy, especially in situations where cardiologists and echocardiography are not accessible. Apart from diagnosis, it may as well be used for followup as well as for prognostication. So, efforts are towards making diagnosis of heart failure simpler.
\end{abstract}

\section{MATERIALS AND METHODS}

Patients admitted in Cardiology Ward, K R Hospital, attached to Mysore Medical College and Research Institute between January 2015 and August 2016 with reduced left ventricular ejection fraction on 2D echocardiography were selected as cases. Forty patients diagnosed with congestive cardiac failure were selected as the cases; 40 subjects with normal 2D echocardiography with normal renal function tests, normal $\mathrm{Hb} \%$, normal BMI were selected as controls.

\section{RESULTS}

The median value of NT pro-BNP was $2294 \mathrm{pg} / \mathrm{mL}$ in a total of 11 cases of acute heart failure. The median value was $3450 \mathrm{pg} / \mathrm{mL}$ in 29 patients with chronic heart failure. The median of acute and chronic heart failure cases taken together was $3193 \mathrm{pg} / \mathrm{mL}$. Among the controls, the median value was $<20 \mathrm{pg} / \mathrm{mL}$. Clearly, the cases had elevated blood levels of NT pro-BNP as compared to controls. Chronic cases had higher values of $60 \%$ of patients having breathlessness more for more than 1 year had NT pro-BNP values greater than $2000 \mathrm{pg} / \mathrm{mL}$ and majority of them had values $>10,000 \mathrm{pg} / \mathrm{mL} ; 57 \%$ of patients with breathlessness of duration of 1 - 12 months had values $>2000 \mathrm{pg} / \mathrm{mL}$ and majority of them had values between $2000-10,000 \mathrm{pg} / \mathrm{mL} ; 50 \%$ of the patients having breathlessness for 1 to 4 weeks had values between $1000-2000 \mathrm{pg} / \mathrm{mL} ; 71 \%$ of patients with Grade 4 NYHA failure had NT pro-BNP values above $2000 \mathrm{pg} / \mathrm{mL}$; 55\% of patients with Grade 3 NYHA failure had NT pro-BNP values of $2000 \mathrm{pg} / \mathrm{mL}$ and $45 \%$ of Grade 3 NYHA failure had NT pro-BNP values between $100-2000$ pg/mL; 50\% each of patients with Grade 2 NYHA failure had values below and above $2000 \mathrm{pg} / \mathrm{mL} ; 78 \%$ of the patients with $\mathrm{LVEF}<30 \%$ had NT pro-BNP levels $>2000 \mathrm{pg} / \mathrm{mL}, 22 \%$ cases had values $<2000 \mathrm{pg} / \mathrm{mL} ; 37 \%$ of patients with EF of $30 \%-40 \%$ had $>2000 \mathrm{pg} / \mathrm{mL}, 63 \%$ of patients with LVEF $31 \%-40 \%$ had NT pro-BNP levels $<2000 \mathrm{pg} / \mathrm{mL}$. There were three cases of LVEF $>40 \%$ in the study and one had $<2000 \mathrm{pg} / \mathrm{mL}$, while two others had $>2000 \mathrm{pg} / \mathrm{mL}$.

\section{CONCLUSION}

This study emphasises the role of NT pro-BNP in the diagnosis of congestive heart failure. The level of NT pro-BNP rises exponentially with the onset of heart failure in contrast to BNP. So this creates a gross difference in blood values of NT pro-BNP in patients with congestive heart failure as compared to those without congestive failure. It also suggests its role in quantifying the degree of failure and duration of illness. So, NT pro-BNP is useful, both as a qualitative and quantitative test in congestive heart failure.

\section{KEYWORDS}

NT pro-BNP; Congestive Heart Failure; NYHA, LVEF.

HOW TO CITE THIS ARTICLE: Gowda L, Raju BMM. A clinical study of N-terminal pro-BNP levels in congestive heart failure. J. Evolution Med. Dent. Sci. 2017;6(13):1000-1004, DOI: 10.14260/Jemds/2017/214

Financial or Other, Competing Interest: None.

Submission 13-01-2017, Peer Review 28-01-2017,

Acceptance 01-02-2017, Published 13-02-2017.

Corresponding Author:

Dr. Laxme Gowda,

Associate Professor,

Mysore Medical College \& Research Institute,

Mysore.

E-mail: laxmegowda@gmail.com

DOI: $10.14260 /$ jemds $/ 2017 / 214$

(c) $($ ) $९$

\section{BACKGROUND}

Heart failure is one of the leading cause of morbidity and mortality in the populations across the globe, as it is a common end point of many diseases, viz. coronary artery diseases, cardiomyopathies, hypertension and many others enumerated in the forthcoming sections. ${ }^{1,2}$ So methodical management of this ailment will play a vital role in preventing unnecessary mortality and morbidity. Lot of research has been done in relation to better understanding of the pathophysiology of this disease as well as in the 
diagnostic and therapeutic techniques related to heart failure till date. Echocardiography in particular has revolutionised the diagnosis of heart failure. In the forthcoming sections, we are focussing on a very simple and quick method of diagnosis of heart failure, viz. NT pro-BNP level estimation ${ }^{3,4}$ which neither needs the echocardiography gadgets nor a skilled echotechnician/cardiologist to interpret the echocardiographic images.5,6 This might prove very handy, especially in situations where cardiologists and echocardiography are not accessible. Apart from diagnosis, it may as well be used for followup as well as for prognostication. 7,8 So, our efforts are towards making diagnosis of heart failure simpler.

\section{Objectives}

1. To look for levels of NT pro-BNP in patients with heart failure.

2. To look for correlation of the NT pro-BNP levels and the NYHA class of Heart Failure.

3. To look for the role of other variables such as age on the levels of NT pro-BNP in a patient with heart failure.

\section{MATERIALS AND METHODS}

\section{Source of Data}

After taking Ethical Committee Clearance and Informed Consent, patients were admitted in Cardiology Ward, KR Hospital, attached to Mysore Medical College and Research Institute between January 2015 and August 2016 with reduced left ventricular ejection fraction on 2D echocardiography were selected for the study.

\section{Method of Collection of Data \\ Sample Size}

40 patients diagnosed with congestive cardiac failure were selected as the cases; 40 subjects with normal 2D echocardiography with normal renal function tests, normal $\mathrm{Hb} \%$, normal BMI were selected as controls.

\section{Sampling Method}

Simple random sampling.

\section{Inclusion Criteria}

Patients admitted in KR Hospital diagnosed with clinical evidence of congestive heart failure with confirmation on $2 \mathrm{D}$ echocardiography.

\section{Exclusion Criteria}

1. Patients with abnormal renal function tests.

2. Obesity.

3. Anaemia.

Data were collected in a pre-tested proforma including detailed history, clinical examination and relevant investigations after consent.

\section{Patients were subjected to the following Investigations -}

1. $\mathrm{Hb} \%$

2. Total count

3. ESR.

4. Serum Urea.

5. Serum Creatinine.
6. Serum Electrolytes.

7. Liver function tests.

8. Fasting Lipid Profile.

9. Urine albumin, sugar and microscopy.

10. Electrocardiography.

11. Chest x-ray.

12. 2D echocardiography.

13. Serum NT pro-BNP.

\section{RESULTS}

A total of 40 cases of CHF were included in the study, out of which 11 were acute CHF and 29 were chronic CHF. Serum NT pro-BNP levels were measured for all of them. The median value of NT pro-BNP was $2294 \mathrm{pg} / \mathrm{mL}$ in a total of 11 cases of acute heart failure. The median value was 3450 $\mathrm{pg} / \mathrm{mL}$ in 29 patients with chronic heart failure. The median of acute and chronic heart failure cases taken together was $3193 \mathrm{pg} / \mathrm{mL}$. Among the controls, the median value was $<20$ $\mathrm{pg} / \mathrm{mL}$. Clearly, the cases had elevated blood levels of NT proBNP as compared to controls. Chronic cases had higher values.

\begin{tabular}{|c|c|}
\hline Category & $\begin{array}{l}\text { Median Values of NT } \\
\text { Pro-BNP (in pg/mL) }\end{array}$ \\
\hline Acute heart failure & 2294 \\
\hline Chronic heart failure & 4422 \\
\hline Acute and chronic failure & 3193 \\
\hline Controls & $<20$ \\
\hline
\end{tabular}

\section{Risk Factors}

Hypertension

\begin{tabular}{|c|c|c|c|c|c|c|}
\hline \multirow{2}{*}{ Hypertension } & \multicolumn{2}{|c|}{ Cases } & \multicolumn{2}{c|}{ Controls } & \multicolumn{2}{c|}{ Total } \\
\cline { 2 - 7 } & No. & $\mathbf{9}$ & No. & $\mathbf{\%}$ & No. & $\mathbf{\%}$ \\
\hline Present & 10 & 25 & 2 & 5 & 12 & 15 \\
\hline Absent & 30 & 75 & 38 & 95 & 68 & 85 \\
\hline Total & $\mathbf{4 0}$ & $\mathbf{1 0 0}$ & $\mathbf{4 0}$ & $\mathbf{1 0 0}$ & $\mathbf{8 0}$ & $\mathbf{1 0 0}$ \\
\hline Table 2. Hypertension in Cases and Controls \\
\hline
\end{tabular}

$\mathrm{P}=2$.

Risk factor in the form of hypertension was more among the cases (25\%) than among the controls (5\%).

\section{Diabetes Mellitus}

\begin{tabular}{|c|c|c|c|c|c|c|}
\hline Diabetes & \multicolumn{2}{|c|}{ Cases } & \multicolumn{2}{c|}{ Controls } & \multicolumn{2}{c|}{ Total } \\
\cline { 2 - 7 } Mellitus & No. & $\mathbf{\%}$ & No. & $\mathbf{\%}$ & No. & $\%$ \\
\hline Present & 9 & 22.5 & 1 & 2.5 & 10 & 12.5 \\
\hline Absent & 31 & 77.5 & 39 & 97.5 & 70 & 87.5 \\
\hline Total & $\mathbf{4 0}$ & $\mathbf{1 0 0}$ & $\mathbf{4 0}$ & $\mathbf{1 0 0}$ & $\mathbf{8 0}$ & $\mathbf{1 0 0}$ \\
\hline Table 3. Diabetes Mellitus Type 2 in Cases and Controls \\
\hline
\end{tabular}

$\mathrm{P}=0.007$.

Diabetes mellitus type 2 was eight times more prevalent among the cases than among the controls. 


\begin{tabular}{|c|c|c|c|c|c|}
\hline & \multicolumn{4}{|c|}{ NT pro-BNP (pg/mL) } & \multirow[b]{2}{*}{ Total } \\
\hline & $<1000$ & $1001-2000$ & \begin{tabular}{|c|}
$2001-$ \\
10,000
\end{tabular} & $>10,000$ & \\
\hline $\begin{array}{c}\text { Absent } \\
\text { Count \% }\end{array}$ & $\begin{array}{c}0 \\
0 \% \\
\end{array}$ & $\begin{array}{c}0 \\
0 \% \\
\end{array}$ & $\begin{array}{c}1 \\
100 \%\end{array}$ & $\begin{array}{c}0 \\
0 \% \\
\end{array}$ & $\begin{array}{c}1 \\
100 \% \\
\end{array}$ \\
\hline $\begin{array}{l}1-7 \text { Days } \\
\text { Count } \%\end{array}$ & $\begin{array}{c}1 \\
50 \%\end{array}$ & $\begin{array}{c}0 \\
0 \%\end{array}$ & $\begin{array}{c}1 \\
50 \%\end{array}$ & $\begin{array}{c}0 \\
0 \%\end{array}$ & $\begin{array}{c}2 \\
100 \%\end{array}$ \\
\hline $\begin{array}{c}1-4 \\
\text { Weeks } \\
\text { Count \% }\end{array}$ & $\begin{array}{c}0 \\
0 \%\end{array}$ & $\begin{array}{c}4 \\
50 \%\end{array}$ & $\begin{array}{c}3 \\
37.5 \%\end{array}$ & $\begin{array}{c}1 \\
12.5 \%\end{array}$ & $\begin{array}{c}8 \\
100 \%\end{array}$ \\
\hline $\begin{array}{c}1 \text { - } 12 \\
\text { Months } \\
\text { Count \% } \\
\end{array}$ & $\begin{array}{c}5 \\
23.8 \%\end{array}$ & $\begin{array}{c}4 \\
19 \%\end{array}$ & $\begin{array}{c}8 \\
38.1 \%\end{array}$ & $\begin{array}{c}4 \\
19 \%\end{array}$ & $\begin{array}{c}21 \\
100 \%\end{array}$ \\
\hline $\begin{array}{c}>12 \\
\text { Months } \\
\text { Count \% }\end{array}$ & $\begin{array}{c}1 \\
14.3 \%\end{array}$ & $\begin{array}{c}1 \\
14.3 \%\end{array}$ & $\begin{array}{c}2 \\
28.6 \%\end{array}$ & $\begin{array}{c}3 \\
42.9 \%\end{array}$ & $\begin{array}{c}7 \\
100 \%\end{array}$ \\
\hline $\begin{array}{c}\text { Total } \\
\text { Count \% }\end{array}$ & $\begin{array}{c}7 \\
17.9 \%\end{array}$ & $\begin{array}{c}9 \\
23.1 \%\end{array}$ & $\begin{array}{c}15 \\
38.5 \%\end{array}$ & $\begin{array}{c}8 \\
20.5 \%\end{array}$ & $\begin{array}{c}39 \\
100 \%\end{array}$ \\
\hline
\end{tabular}

$\mathrm{P}=0.561$.

$60 \%$ of patients having breathlessness for more than 1 year had NT pro-BNP values $>2000 \mathrm{pg} / \mathrm{mL}$ and majority of them had values $>10,000 \mathrm{pg} / \mathrm{mL} ; 57 \%$ of patients with breathlessness of duration of $1-12$ months had values > $2000 \mathrm{pg} / \mathrm{mL}$ and majority of them had values between 2000 $10,000 \mathrm{pg} / \mathrm{mL} ; 50 \%$ of the patients having breathlessness for 1 to 4 weeks had values between $1000-2000 \mathrm{pg} / \mathrm{mL}$.

\section{LVEF}

\begin{tabular}{|c|c|c|c|c|c|c|}
\hline \multirow{2}{*}{ LVEF } & \multicolumn{2}{|c|}{ Cases } & \multicolumn{2}{c|}{ Controls } & \multicolumn{2}{c|}{ Total } \\
\cline { 2 - 7 } & No. & $\mathbf{\%}$ & No. & $\mathbf{\%}$ & No. & \% \\
\hline$<30$ & 21 & 52.5 & 0 & 0 & 21 & 26.3 \\
\hline $31-40$ & 16 & 40 & 0 & 0 & 16 & 20 \\
\hline $40+$ & 3 & 7.5 & 40 & 100 & 43 & 53.7 \\
\hline Total & $\mathbf{4 0}$ & $\mathbf{1 0 0}$ & $\mathbf{4 0}$ & $\mathbf{1 0 0}$ & $\mathbf{8 0}$ & $\mathbf{1 0 0}$ \\
\hline \multicolumn{6}{|c|}{ Table 5. LVEF in Cases and Controls } \\
\hline
\end{tabular}

$\mathrm{P}=0.000$

$52.5 \%$ of the cases had left ventricular ejection fraction less than $30 \%$

$40 \%$ of patients had EF between $31 \%$ and $40 \%$ and $7.5 \%$ patients had EF between $40 \%$ and $50 \%$.

\section{NT Pro-BNP Levels}

\begin{tabular}{|c|c|c|c|c|c|c|}
\hline NT & \multicolumn{2}{|c|}{ Cases } & \multicolumn{2}{c|}{ Controls } & \multicolumn{2}{c|}{ Total } \\
\cline { 2 - 7 } Pro-BNP (pg/mL) & No. & $\mathbf{\%}$ & No. & $\mathbf{\%}$ & No. & $\%$ \\
\hline$<1000$ & 7 & 17.5 & 40 & 100 & 47 & 58.8 \\
\hline $1001-2000$ & 10 & 25 & 0 & 0 & 10 & 12.5 \\
\hline $20,001-10,000$ & 15 & 37.5 & 0 & 0 & 15 & 18.7 \\
\hline$>10,000$ & 8 & 20 & 0 & 0 & 8 & 10 \\
\hline Total & $\mathbf{4 0}$ & $\mathbf{1 0 0}$ & $\mathbf{4 0}$ & $\mathbf{1 0 0}$ & $\mathbf{8 0}$ & $\mathbf{1 0 0}$ \\
\hline Table 6. NT Pro-BNP Levels in Cases and Control \\
\hline
\end{tabular}

$\mathrm{P}=0.000$

$37.5 \%$ of the cases had values of NT pro-BNP between 2000 and $10,000 \mathrm{pg} / \mathrm{mL}$.

$25 \%$ of cases had values between 1000 and $2000 \mathrm{pg} / \mathrm{mL}$; $20 \%$ of cases had values $>10,000 \mathrm{pg} / \mathrm{mL} ; 17.5 \%$ of cases had values $<1000 \mathrm{pg} / \mathrm{mL}$ and among them only one patient had value less than $100 \mathrm{pg} / \mathrm{mL}$. All controls had values less than $100 \mathrm{pg} / \mathrm{mL}$.
Serum NT pro-BNP Levels and the NYHA Grade of CHF

\begin{tabular}{|c|c|c|c|c|c|}
\hline & \multicolumn{4}{|c|}{ NT pro-BNP (pg/mL) } & \multirow[b]{2}{*}{ Total } \\
\hline & $<1000$ & $\begin{array}{l}1001- \\
2000\end{array}$ & $\begin{array}{c}2001- \\
10,000\end{array}$ & $\begin{array}{c}> \\
10,000\end{array}$ & \\
\hline $\begin{array}{c}\text { Grade } 2 \text { count } \\
\% \text { of GRA.H }\end{array}$ & $\begin{array}{c}1 \\
25.0 \%\end{array}$ & $\begin{array}{c}1 \\
25.0 \%\end{array}$ & $\begin{array}{c}1 \\
25.0 \%\end{array}$ & $\begin{array}{c}1 \\
25.0 \%\end{array}$ & $\begin{array}{c}4 \\
100.0 \%\end{array}$ \\
\hline $\begin{array}{c}\text { Grade } 3 \text { count } \\
\% \text { of GRA.H }\end{array}$ & $\begin{array}{c}6 \\
20.7 \%\end{array}$ & $\begin{array}{c}7 \\
24.1 \%\end{array}$ & $\begin{array}{c}11 \\
37.9 \%\end{array}$ & $\begin{array}{c}5 \\
17.2 \%\end{array}$ & $\begin{array}{c}29 \\
100.0 \%\end{array}$ \\
\hline $\begin{array}{c}\text { Grade } 4 \text { count } \\
\% \text { of GRA.H }\end{array}$ & $\begin{array}{c}0 \\
0 \%\end{array}$ & $\begin{array}{c}2 \\
28.6 \%\end{array}$ & $\begin{array}{c}3 \\
42.9 \%\end{array}$ & $\begin{array}{c}2 \\
28.6 \%\end{array}$ & $\begin{array}{c}7 \\
100.0 \%\end{array}$ \\
\hline $\begin{array}{c}\text { Total count } \% \\
\text { of GRA.H }\end{array}$ & $\begin{array}{c}7 \\
17.5 \%\end{array}$ & $\begin{array}{c}10 \\
25.0 \%\end{array}$ & $\begin{array}{c}15 \\
37.5 \%\end{array}$ & $\begin{array}{c}8 \\
20.0 \%\end{array}$ & $\begin{array}{c}40 \\
100.0 \%\end{array}$ \\
\hline & le 7. Se & um NT & ro-BNP & evels & \\
\hline
\end{tabular}

$71 \%$ of patients with Grade 4 NYHA failure had NT proBNP values above $2000 \mathrm{pg} / \mathrm{mL}$; 55\% of patients with Grade 3 NYHA failure had NT pro-BNP values of $2000 \mathrm{pg} / \mathrm{mL}$ and $45 \%$ of Grade 3 NYHA failure had NT pro-BNP values between 100 and $2000 \mathrm{pg} / \mathrm{mL} ; 50 \%$ each of patients with Grade 2 NYHA failure had values below and above 2000 $\mathrm{pg} / \mathrm{mL}$.

\section{LVEF and Serum NT pro-BNP levels}

\begin{tabular}{|c|c|c|c|c|c|}
\hline & \multicolumn{4}{|c|}{ NT pro-BNP (pg/mL) } & \multirow{2}{*}{ Total } \\
\cline { 2 - 5 } & $<\mathbf{1 0 0 0}$ & $\begin{array}{c}\mathbf{1 0 0 1}-\mathbf{2 0 0 1 -} \\
\mathbf{2 0 0 0}\end{array}$ & $\begin{array}{c}\mathbf{1 0 , 0 0 0} \\
\mathbf{1 0 , 0 0 0}\end{array}$ & \\
\hline $\begin{array}{c}\text { LVEF }<30 \\
\text { count \% of } \\
\text { LVEF }\end{array}$ & 1 & 5 & 10 & 5 & 21 \\
\hline $\begin{array}{c}31 \text { - 40 count } \\
\% \text { of LVEF }\end{array}$ & $5.8 \%$ & $23.8 \%$ & $47.6 \%$ & $23.8 \%$ & $100.0 \%$ \\
\hline $\begin{array}{c}40+\text { count } \% \\
\text { of LVEF }\end{array}$ & 1 & 5 & 4 & 2 & 16 \\
\hline $\begin{array}{c}\text { Total count } \\
\% \text { of LVEF }\end{array}$ & $73.3 \%$ & $.0 \%$ & $33.3 \%$ & $33.3 \%$ & $100.0 \%$ \\
\hline Table 8. LVEF and Serum NT Pro-BNP Levels \\
\hline
\end{tabular}

$78 \%$ of the patients with LVEF $<30 \%$ had NT pro-BNP levels $>2000 \mathrm{pg} / \mathrm{mL}, 22 \%$ cases had values $<2000 \mathrm{pg} / \mathrm{mL}$; $37 \%$ of patients with EF of $30 \%-40 \%$ had $>2000 \mathrm{pg} / \mathrm{mL}$ $63 \%$ of patients with LVEF $31 \%-40 \%$ had NT pro-BNP levels $<2000 \mathrm{pg} / \mathrm{mL}$. There were three cases of LVEF $>40 \%$ in the study and one had $<2000 \mathrm{pg} / \mathrm{mL}$, while two others had $>$ $2000 \mathrm{pg} / \mathrm{mL}$.

\section{DISCUSSION}

In present study the median concentration of NT pro-BNP were 2624, 3193 and $<20 \mathrm{pg} / \mathrm{mL}$ amongst the acute $\mathrm{CHF}$, chronic CHF and controls. Januzzi et $\mathrm{al}^{8,9}$ study showed that for diagnosis of acute CHF cut-off of $>450 \mathrm{pg} / \mathrm{mL}$ and $>900$ $\mathrm{pg} / \mathrm{mL}$ for $<50$ years and $>50$ years group respectively were highly sensitive and specific. McDonough et al ${ }^{10}$ study had median NT pro-BNP values of $269.6 \mathrm{pg} / \mathrm{mL}$ congestive heart failure.

\begin{tabular}{|c|c|c|}
\hline \multirow{2}{*}{} & \multicolumn{2}{|c|}{ NT pro-BNP Median values (pg/mL) } \\
\cline { 2 - 3 } & Present Study & McDonough et al Study \\
\hline CHF & 3193 & 269.6 \\
\hline Controls & $<20$ & 20 \\
\hline Table 9. Median Serum NT Pro-BNP Levels \\
\hline
\end{tabular}


Yoshihiko et $\mathrm{al}^{7}$ showed that blood level of NT pro-BNP rises exponentially with clinical grade of heart failure: Levels in Class II NYHA CHF were 25 times more than in class I NYHA. Levels in Class III NYHA CHF cases were 100 times more than in Class I NYHA.

In the present study 29 cases were Grade III NYHA, 7 cases were Grade IV NYHA and 4 were Grade II NYHA CHF. The higher median value in the present study thus could be because most of the cases were Grade III or IV NYHA congestive heart failures.

Among cases 11 cases were acute heart failure and their median value was $2294 \mathrm{pg} / \mathrm{mL}$. Among the 29 chronic heart failure cases, the median was $4422 \mathrm{pg} / \mathrm{mL}$.

Thus, chronic cases had more median value than the acute cases. There were 7 cases who had values less than 1000 $\mathrm{pg} / \mathrm{mL}$, out of which one was acute and others were chronic. This probably could be explained because many of the chronic cases were already begun on treatment by the time they were referred to the tertiary centre at KR Hospital. Studies have shown that the values start dropping significantly if heart failure is optimally treated.11,12

In this study, we had higher values of NT pro-BNP in patients of age above 60 years as compared to those below 60 years: $56 \%$ of patients below 60 years had values above 2000 $\mathrm{pg} / \mathrm{mL}$, whereas $73 \%$ of patients aged above 60 years had values above $2000 \mathrm{pg} / \mathrm{mL}$.

Bay et $\mathrm{al}^{13}$ showed higher values of NT pro-BNP in elderly patients. The cause of which was attributed to poorer GFR in elderly patients. Thus, this justifies that age could behave as a confounding factor provided a different cut-off was taken for elderly and others.

\begin{tabular}{|c|c|c|c|}
\hline & $\begin{array}{c}\text { Present Study } \\
(\mathbf{n = 4 0 )}\end{array}$ & $\begin{array}{c}\text { Yoshihiko et al } \\
(\mathbf{n}=\mathbf{3 9 0})\end{array}$ & $\begin{array}{c}\text { Bay et al } \\
(\mathbf{n = 2 1 9 3})\end{array}$ \\
\hline $\begin{array}{c}\text { Mean NT } \\
\text { pro-BNP values in } \\
>60 \text { years as } \\
\text { Compared } \\
\text { to }<60 \text { years }\end{array}$ & Higher & Higher & Higher \\
\hline \multicolumn{2}{|c|}{ Table 10. Mean Serum NT Pro-BNP in } \\
People $>60$ Years and < 60 Years \\
\hline
\end{tabular}

This study had fairly equal proportion of male and female cases. There was no significant difference in the NT pro-BNP values among males and females for a given NYHA class heart failure and for a given LVEF. Studies done by Yoshihiko et al showed significant higher values in females for a given class of heart failure.

\begin{tabular}{|c|c|c|c|}
\hline & $\begin{array}{c}\text { Present } \\
\text { Study (n=40) }\end{array}$ & $\begin{array}{c}\text { Yoshihiko } \\
\text { et al (n=390) }\end{array}$ & $\begin{array}{c}\text { Bay et al } \\
(\mathbf{n = 2 1 9 3})\end{array}$ \\
\hline $\begin{array}{c}\text { Values of NT } \\
\text { pro-BNP in }\end{array}$ & No & $\begin{array}{c}\text { Females } \\
\text { > Males }\end{array}$ & $\begin{array}{c}\text { Females } \\
>\text { Males }\end{array}$ \\
$\begin{array}{c}\text { Females as } \\
\text { compared to } \\
\text { Males }\end{array}$ & Difference & \multicolumn{3}{|c|}{ Table 11. Mean Serum NT Pro-BNP } \\
Values in Females versus Males \\
\hline
\end{tabular}

Present study shows correlation between levels of NT pro-BNP and the duration of exertional breathlessness, which is a cardinal symptom of congestive heart failure. Exertional breathlessness was a presenting complaint in 39 out of the 40 cases in the present study; $60 \%$ of patients having breathlessness for more than 1 year had NT pro-BNP values greater than $2000 \mathrm{pg} / \mathrm{mL}$ and majority of them had values > $10,000 \mathrm{pg} / \mathrm{mL} ; 57 \%$ of patients with breathlessness of duration of 1 - 12 months had values $>2000 \mathrm{pg} / \mathrm{mL}$ and majority of them had values between 2000 and 10,000 $\mathrm{pg} / \mathrm{mL} ; 50 \%$ of the patients having breathlessness for 1 to 4 weeks had values between 1000 and $2000 \mathrm{pg} / \mathrm{mL}$.

This prompts at a prospect of using this marker to not only classify severity of heart failure, but also as a marker of duration of heart failure. As of now, no studies have compared levels of NT pro-BNP levels in acute and chronic heart failure cases. In the present study, most of the cases were ischaemic congestive heart failure. So the correlation of NT pro-BNP levels to the aetiology of CHF could not be commented upon. In Copernicus sub-study, ${ }^{14}$ it was shown that the levels of NT pro-BNP were higher in patients with ischaemic CHF as compared to those with non-ischaemic CHF.

In the present study, there was a correlation of the NYHA grade of the heart failure to the levels of NT pro-BNP.

\begin{tabular}{|c|c|c|c|}
\hline & $\begin{array}{c}\text { Grade II } \\
\text { NYHA CHF }\end{array}$ & $\begin{array}{c}\text { Grade III } \\
\text { NYHA CHF }\end{array}$ & $\begin{array}{c}\text { Grade IV } \\
\text { NYHA CHF }\end{array}$ \\
\hline $\begin{array}{c}\text { Median NT pro-BNP } \\
\text { Levels in Present Study }\end{array}$ & 2491 & 2953 & 7329 \\
\hline $\begin{array}{c}\text { Mean NT pro-BNP } \\
\text { Levels in Study at Iowa }\end{array}$ & 1666 & 3029 & 3465 \\
\hline \multicolumn{4}{|c|}{ Table 12. Serum NT Pro-BNP Values } \\
in various NYHA Grade of CHF \\
\hline
\end{tabular}

In the present study, there is a correlation between the LVEF and the NT pro-BNP levels in the plasma; $71 \%$ patients having LVEF of $<30 \%$ had NT pro-BNP levels above 2000 $\mathrm{pg} / \mathrm{mL}, 63 \%$ of patients with LVEF of $31 \%-40 \%$ had NT proBNP levels between 1000 and $2000 \mathrm{pg} / \mathrm{mL}$. These results are in tune with PRIDE study ${ }^{9}$ and Yoshihiko et al $^{7}$ study.

\begin{tabular}{|c|c|c|c|}
\hline & $\begin{array}{c}\text { Present } \\
\text { Study } \\
(\mathbf{n = 4 0 )}\end{array}$ & $\begin{array}{c}\text { Pride } \\
\text { Study } \\
(\mathbf{n = 2 0 9})\end{array}$ & $\begin{array}{c}\text { Yoshihiko } \\
\text { et al } \\
(\mathbf{n}=390)\end{array}$ \\
\hline $\begin{array}{c}\text { Correlation between } \\
\text { LVEF and NT pro-BNP } \\
\text { Levels }\end{array}$ & Present & Present & Present \\
\hline \multicolumn{3}{|c|}{ Table 13. LVEF and Serum NT Pro-BNP Levels } \\
\hline
\end{tabular}

\section{CONCLUSION}

Present study emphasises on the role of NT pro-BNP in the diagnosis of congestive heart failure. The level of NT pro-BNP rises exponentially with the onset of heart failure in contrast to BNP. So this creates a gross difference in blood values of NT pro-BNP in patients with congestive heart failure as compared to those without congestive failure.

It also suggests its role in quantifying the degree of failure and duration of illness. So NT pro-BNP is useful both as a qualitative and quantitative test in congestive heart failure.

\section{Summary}

This a case control study of levels of NT pro-BNP among 40 cases of CHF patients admitted in $\mathrm{K}$ R Hospital during the period of January 2015 to August 2016 who were randomly selected and NT pro-BNP measured along with recording other historical and investigational variables. Cases were compared with matched controls.

There was a median value of $3193 \mathrm{pg} / \mathrm{mL}$ among the cases, $2624 \mathrm{pg} / \mathrm{mL}$ among acute cases and $3450 \mathrm{pg} / \mathrm{mL}$ among chronic cases, whereas median in controls were $<20$ 
$\mathrm{pg} / \mathrm{mL}$. NT pro-BNP values were higher among patients above 60 years as compared to patients younger to them.

Patients with longer duration of exertional breathlessness had higher values as compared to those with lesser duration of breathlessness, i.e. patients with chronic heart failure had values higher than those with acute heart failure. Higher values of NT pro-BNP were found among patients with higher clinical grade of heart failure and patients with lesser ejection fraction had higher median value of NT pro-BNP. Sex had no bearing on the levels of NT pro-BNP in this study.

\section{REFERENCES}

[1] Douglas L Mann. Disorders of heart, heart failure and cor pulmonale. In: Dan L Longo, Fauci A, Kasper D, et al, eds. Harrison's principles of internal medicine. 18 th edn. New York: McGraw-Hill 2011:1901-15.

[2] Francis GS, Tang WHW, Walsh RA. Pathophysiology of heart failure. Chapter 26. In: Fuster V, Walsh RA, Harrington RA, ed. Hurst's the heart. 13 th edn. New York: McGraw-Hill 2004:719-38.

[3] Goetze JP. Biochemistry of Pro-B-Type natriuretic peptide-derived peptides: the endocrine heart revisited. Clinical Chemistry 2004;50(9):1503-10.

[4] Hall C. Essential biochemistry and physiology of (NTpro)BNP. Eur J Heart Fail 2004;6(3):257-60.

[5] Weber M, Hamm C. Role of B-type natriuretic peptide (BNP) and NT-proBNP in clinical routine. Heart 2006;92(6):843-9.

[6] Pfisher R, Scholz M, Wielcken K, et al. Use of NTproBNP in routine testing and comparison to BNP. Eur J Heart Fail 2003;6(3):289-93.

[7] Seino Y, Ogawa A, Yamashita T, et al. Application of NT-proBNP measurements in cardiac case: a more discerning marker for detection and evaluation of heart failure. Eur J Heart Fail 2003;6(3):295-300.
[8] Januzzi JL, van Kimmenade R, Lainchbury J, et al. NTproBNP testing for diagnosis and short-term prognosis in acute destabilized heart failure: an international pooled analysis of 1256 patients: the International Collaborative of NT-proBNP Study. Eur Heart J2006;27(3):330-7.

[9] Januzzi JL, Camargo CA, Anwaruddin S, et al. The Nterminal Pro-BNP investigation of dyspnea in the emergency department (PRIDE) study. Am J Cardiol 2005;95(8):948-54.

[10] McDonagh TA, Holmer S, Raymond L, et al. NT-proBNP and the diagnosis of heart failure: a pooled ananlysis of three European epidemiological studies. Eur J Heart Fail 2004;6(3):269-73.

[11] Blyth KG, Groenning BA, Mark PB, et al. NT-proBNP can be used to detect right ventricular systolic dysfunction in pulmonary hypertension. Eur Respir J 2007;29(4):737-44.

[12] Shah KB, Nolan MM, Rao K, et al. The characteristics and prognostic importance of NT-proBNP concentrations in critically ill patients. Am J Med 2007;120(12):1071-7.

[13] Bay M, Kirk V, Parner J, et al. NT-proBNP: a new diagnostic screening tool to differentiate between patients with normal and reduced left ventricular systolic function. Heart 2003;89(2):150-4.

[14] Hartmann F, Packer M, Coats AJ, et al. NT-proBNP in severe chronic heart failure: rationale, design and preliminary results of the COPERNICUS NT-proBNP substudy. Eur J Heart Fail 2004;6(3):343-50. 